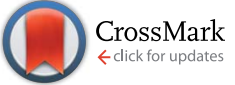

Cite this: RSC Adv., 2015, 5, 34415

\title{
Bis(imidazolium) salts derived from amino acids as receptors and transport agents for chloride anions $\uparrow$
}

\author{
Laura González-Mendoza, ${ }^{a}$ Belén Altava, ${ }^{* a}$ M. Isabel Burguete, ${ }^{a}$ Jorge Escorihuela, ${ }^{b}$ \\ Elsa Hernando, ${ }^{c}$ Santiago V. Luis, ${ }^{* a}$ Roberto Quesada ${ }^{c}$ and Cristian Vicent ${ }^{d}$
}

Received 2nd April 2015

Accepted 8th April 2015

DOI: $10.1039 / \mathrm{c} 5 \mathrm{ra05880e}$

www.rsc.org/advances
The binding properties of bis(imidazolium) hosts $1 \mathrm{a}-\mathrm{c}$ derived from amino acids towards different anions have been studied by ${ }^{1} \mathrm{H}$ NMR titration experiments in $95: 05 \mathrm{CD}_{3} \mathrm{CN}: \mathrm{H}_{2} \mathrm{O}$ at $303 \mathrm{~K}$, ESI-MS and theoretical calculations. Among this family, the salt $1 \mathrm{c}$ showed a strong and high selectivity for chloride anions. Transmembrane chloride transport activity has also been studied for the three bis(imidazolium) based transporters in POPC liposome models, and compound 1a was identified as an active chloride/ nitrate exchanger.

\section{Introduction}

Considerable attention continues to be shown in the design and synthesis of anion receptors possessing high affinity and selectivity. ${ }^{1}$ In this regard, anionic species are of biological and environmental importance, ${ }^{2}$ chloride being the most abundant anion in living organisms. ${ }^{3}$ The proper design, synthesis and study of abiotic hosts allows a minimalistic approach to the binding phenomena, largely simplifying the deep understanding of the corresponding processes. ${ }^{4}$ Recently, numerous efforts have been devoted to the study of imidazolium receptors, including benzene-based tripodal systems, cyclophane and caliximidazolium, fluorescent imidazolium, ferrocenyl imidazolium, cavitand and calixarene, and polymeric imidazolium systems. ${ }^{5,6}$ In contrast to the well-known $\mathrm{N}-\mathrm{H}$-anion or $\mathrm{N}^{+}-\mathrm{H}-$ anion hydrogen bonding, which is often found in amide, pyrrole, urea, ammonium or guanidinium groups, the imidazolium group can interact with anions through the involvement of $(\mathrm{C}-\mathrm{H})^{+}$-anion hydrogen bonds and, usually, the recognition is dominated by charge-charge electrostatic interactions. ${ }^{7,8}$

Furthermore, the transport of chloride across cell membranes is important to numerous biological processes, and is often mediated by proteins that act as anion pores, anion

${ }^{a}$ Departamento de Química Inorgánica y Orgánica, Universitat Jaume I, Av. Sos Baynat, s/n, E-12071 Castellón, Spain. E-mail: luiss@uji.es; altava@uji.es; Fax: +34 964728214

${ }^{b}$ Wageningen UR, Laboratory of Organic Chemistry, Dreijenplein 8, $6703 \mathrm{HB}$ Wageningen, The Netherlands

'Departamento de Quimica, Facultad de Ciencias, Universidad de Burgos, 09001 Burgos, Spain

${ }^{a}$ Serveis Centrals d'Instrumentació Cientifica, Universitat Jaume I, Avda. Sos Baynat, $s / n, 12071$ Castellón, Spain

$\dagger$ Electronic supplementary information (ESI) available: ${ }^{1} \mathrm{H}$ NMR titration experiments and HypNMR fitting data, ESI-MS experiments and chloride transport studies and theoretical data. See DOI: 10.1039/c5ra05880e exchangers or cation-dependent co-transporters. ${ }^{9}$ Malfunction of these proteins, through genetic mutation or otherwise, can lead to diseases such as cystic fibrosis. ${ }^{10}$ With this in mind, much focus is being placed on the development of small synthetic molecules that can mimic the role of such proteins. ${ }^{11}$ Optimizing their potential to bind or encapsulate ions, such synthetic "carriers" could be developed for therapeutic applications. ${ }^{12}$ In this context, the biocompatibility of the imidazole ring makes it suitable for biomimetic applications,${ }^{13}$ and it has previously been incorporated in the structure of transmembrane carriers by Gale et $a l^{14}$ and more recently by Schmitzer et al., ${ }^{15}$ representing a new class of potential anion transporters.

In this regard, our research group has been involved in the preparation of imidazolium based receptors derived from enantiomerically pure materials obtained from the chiral pool. ${ }^{16}$ We have recently reported the synthesis of new ditopic dicationic receptors derived from amino acids with the general structure shown in Fig. 1, as receptors for the recognition of the chiral anions of dicarboxylic acids. ${ }^{17}$ As an extension of this work, here we report their use of as receptors for inorganic anions such as the spheric chloride, bromide and iodide anions

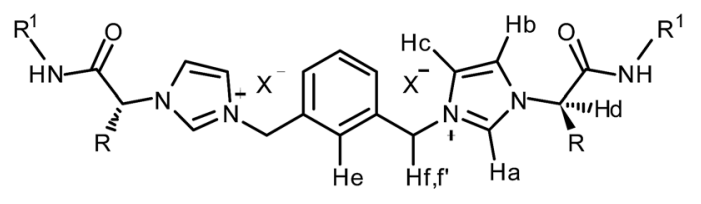

$$
\begin{aligned}
& \text { 1a: } \mathrm{R}=\mathrm{Bn} ; \mathrm{R}^{1}=\mathrm{Bn} \\
& \text { 1b: } \mathrm{R}=\mathrm{CH}\left(\mathrm{CH}_{3}\right)_{2} ; \mathrm{R}^{1}=\mathrm{Bn} \\
& \text { 1c: } \mathrm{R}=\mathrm{CH}\left(\mathrm{CH}_{3}\right)_{2} ; \mathrm{R}^{1}=\left(\mathrm{CH}_{2}\right)_{11} \mathrm{CH}_{3}
\end{aligned}
$$

Fig. 1 General structure of receptors 1a-c, prepared as their bis(trifluoromethylsulfonyl)imide salts, $\mathrm{X}^{-}=\mathrm{NTf}_{2}{ }^{-}$. 
and the trigonal $\mathrm{NO}_{3}{ }^{-}$anion. The corresponding anion complexation properties have been investigated by ${ }^{1} \mathrm{H}$ NMR spectroscopy, ESI-MS and computational studies. Besides, these receptors have been studied as transmembrane transporters for chloride anion.

\section{Results and discussion}

Chiral bis(imidazolium) compounds (1a-c) derived from different amino acids with variable $N$-amide substitution were prepared following the procedure described previously by our group. ${ }^{17}$

In preliminary recognition studies the interaction of the dicationic receptors 1a-c with chloride was studied by ${ }^{1} \mathrm{H}$ NMR titrations with the corresponding tetrabutylammonium (TBA) salt using $\mathrm{CDCl}_{3}(5 \% \mathrm{DMSO})$ as the solvent at $303 \mathrm{~K}$. The corresponding binding constants could not be calculated due the strong association with chloride in this medium. Thus, we studied the interaction between receptors $\mathbf{1 a - c}$ and chloride using a more competitive solvent like aqueous $\mathrm{CD}_{3} \mathrm{CN}$. Fig. 2 shows the chemical shift variation of the different protons of receptor 1c during titration experiments with TBACl in $\mathrm{CD}_{3} \mathrm{CN}$ $\left(5 \% \mathrm{D}_{2} \mathrm{O}\right)$. Most of the signals of the receptor were affected by the presence of the chloride anion, although the overlapping of some of them precluded their accurate quantitative analysis. The signals more affected by the interaction were those corresponding to $\mathrm{Ha}, \mathrm{NH}, \mathrm{Hb}, \mathrm{He}$ and $\mathrm{Hd}$ (see Fig. 1 for the identification of the corresponding hydrogen atoms). These variations suggested a strong electrostatic and H-bonding interaction between 1c and the anion. The same trends in the chemical shifts variations were obtained with receptors 1a and 1b (see $\mathrm{ESI}^{\dagger}$ ). It is interesting to note that the signal corresponding to the proton $\mathrm{He}$ of the central aromatic spacer is also significantly shifted to lower fields in the presence of $\mathrm{Cl}^{-}$along with the signals corresponding to the hydrogen atoms of the imidazolium subunit (including $\mathrm{Hb}$ and $\mathrm{Hc}$, although at a lower extent). Interestingly, the diastereotopic methylene $\mathrm{Hf}, \mathrm{f}^{\prime}$ hydrogen atoms become less equivalent as chloride is added,

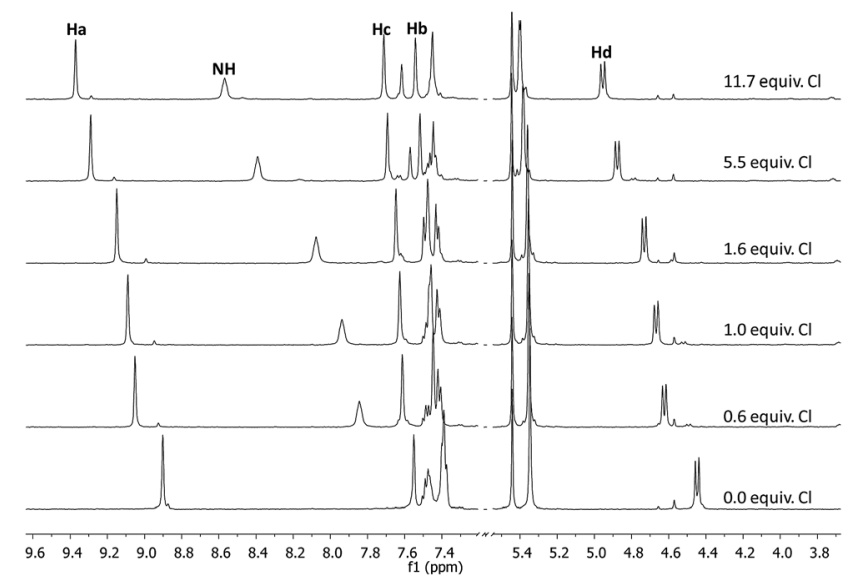

Fig. 2 Partial ${ }^{1} \mathrm{H}$ NMR spectra $\left(500 \mathrm{MHz}, 5 \%\right.$ aqueous $\mathrm{CD}_{3} \mathrm{CN}$ at $303 \mathrm{~K}$ ) of $1 \mathrm{c}(5 \mathrm{mM})$ in the presence of different amounts of TBACl. which is more evident when the less polar solvent $\left(\mathrm{CDCl}_{3}\right)$ is used (see ESI $\dagger$ ). ${ }^{17}$

The stoichiometry of the resulting host-guest complex was then investigated by ${ }^{1} \mathrm{H}$ NMR using the Job plot method. ${ }^{18}$ The Job-plot for the complexation of 1c with the chloride anion in $\mathrm{CD}_{3} \mathrm{CN}\left(5 \% \mathrm{D}_{2} \mathrm{O}\right)$ exhibit a maximum at $X_{\mathrm{L}}=0.5$ for the different proton signals of compound 1c analysed, which indicates that the $1: 1$ complex is predominant in solution (see $\mathrm{ESI} \dagger)$.

The data obtained from the titration experiments using compound 1c are shown in Fig. 3, displaying the corresponding isotherms for the binding of chloride anion. As can be observed, the most affected proton signal is the NH for which $\Delta \delta_{\max }>1$ ppm.

The simultaneous fitting of the variation of the chemical shifts of the five ${ }^{1} \mathrm{H}$ NMR proton signals of the different receptors rendered the corresponding binding constants which were determined fitting the data to a $1: 1$ and $1: 2$ receptor: anion binding isotherm using the HypNMR program (Table 1). ${ }^{19}$ The receptor $1 \mathrm{c}$ showed a strong interaction with chloride even in this competitive medium, and formed a stable $1: 1$ complex $\left(K_{\mathrm{a}} 10^{3.2}\right)$ with an additional weaker interaction with a second chloride anion $\left(K_{\mathrm{a}} 10^{1.4}\right)$. Interestingly, the binding constant for $\mathbf{1 c}$ is eight times higher than for $\mathbf{1 b}$ for the 1 : 1 complex (Table 1 ). We also determined the $\mathrm{BC}_{50}^{0}$ parameter for a suitable comparison between ligands. ${ }^{20}$ This parameter is defined here as the concentration of anion needed to bind $50 \%$ of the dication and, thus, the lower the $\mathrm{BC}_{50}^{0}$ value the stronger the supramolecular host-guest interaction. As expected, this parameter also shows with clarity the same trends detected in the values of the association constants, with the $\mathrm{BC}_{50}^{0}$ value for chloride being significantly lower for $1 \mathrm{c}(0.6 \mathrm{mM})$, the valine derivative containing additional long aliphatic tails. When comparing the role of the amino acid residue (1a against $\mathbf{1 b}$ ), the results suggest that this structural parameter does not have a strong influence on the anion recognition (Table 1, entries 1 and 2), while the nature of $\mathrm{R}^{1}$ seems to have a bigger effect (Table 1, entries 2 and 3). Most likely, according to modeling studies on the receptors and complexes, $\mathrm{R}^{1}$ substituents play an

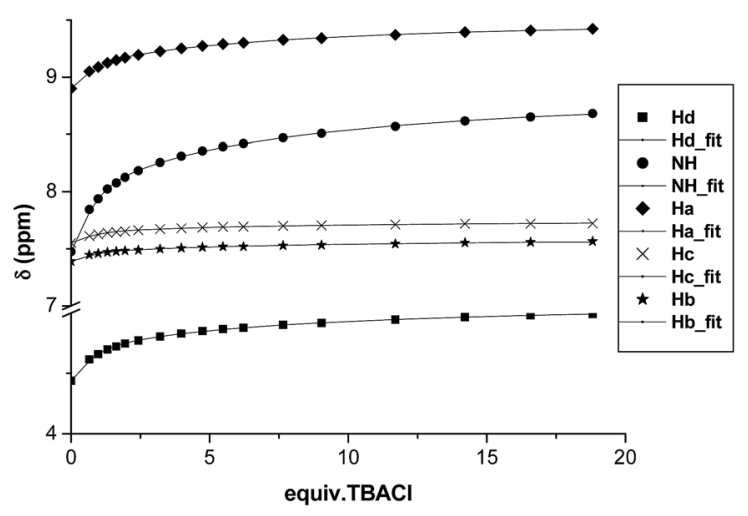

Fig. $3{ }^{1} \mathrm{H}$ NMR (500 MHz, $5 \%$ aqueous $\mathrm{CD}_{3} \mathrm{CN}$ at $303 \mathrm{~K}$ ) titration plot of $1 \mathrm{c}(5 \mathrm{mM})$ versus the equiv. of TBACl added. Symbols represent the experimental chemical shifts; lines correspond to the calculated ones for the best fitting. 
Table 1 Binding constants for the interaction of $1 \mathrm{a}-\mathrm{c}$ with chloride, as its TBA salt, determined by ${ }^{1} \mathrm{H} N M R$ in $5 \% \mathrm{D}_{2} \mathrm{O}$ in $\mathrm{CD}_{3} \mathrm{CN}$ at $500 \mathrm{MHz}$ and $303 \mathrm{~K}$

\begin{tabular}{lllll}
\hline Entry & Receptor $^{a}$ & $\begin{array}{l}\log \beta^{b} \\
\text { (receptor-anion) }\end{array}$ & $K_{\mathrm{a}}$ & BC $_{50}^{0}[\mathrm{mM}]$ \\
\hline \multirow{2}{*}{1} & \multirow{2}{*}{ 1a } & $2.16 \pm 0.02(1: 1)^{c}$ & $145(1: 1)$ & $(6.7 \pm 0.3)$ \\
& & $2.61 \pm 0.09(1: 2)^{d}$ & $3(1: 2)$ & \\
2 & \multirow{2}{*}{ 1b } & $2.28 \pm 0.02(1: 1)^{c}$ & $191(1: 1)$ & $(5.0 \pm 0.2)$ \\
& & $3.0 \pm 0.1(1: 2)^{d}$ & $5(1: 2)$ & \\
3 & 1c & $3.20 \pm 0.08(1: 1)^{c}$ & $1585(1: 1)$ & $(0.6 \pm 0.1)$ \\
& & $4.6 \pm 0.1(1: 2)^{d}$ & $25(1: 2)$ &
\end{tabular}

${ }^{a}$ As the bis(trifluoromethylsulfonyl)imide salt. ${ }^{b}$ Obtained by the simultaneous non-linear regression fitting of all the available ${ }^{1} \mathrm{H}$ NMR signals using the HypNMR program. ${ }^{c} \beta(1: 1)$ is defined as the formation constant for the $1: 1$ receptor/substrate complex in $\mathrm{M}^{-1}$. ${ }^{d}$ In this case $\beta(1: 2)$ is the cumulative formation constant for the corresponding $1: 2$ receptor/substrate complex in $\mathrm{M}^{-2}$.

important role in defining conformational preferences, in particular the nature of folding, which could explain this trend.

As a function of these initial results, the interaction of the receptor 1c with other spherical anions, such as bromide and iodide, and the trigonal $\left(\mathrm{NO}_{3}{ }^{-}\right)$, was also studied. The results obtained showed that the corresponding binding constants were more than one order of magnitude smaller than that for chloride (Table 2), indicating the weaker interaction of these anions with the bis(imidazolium) receptor. According to these results, the interaction for the different anions is $\mathrm{Cl}^{-} \gg \mathrm{Br}^{-}>$ $\mathrm{I}^{-} \sim \mathrm{NO}_{3}{ }^{-}$. As observed, in the case of the halogen anions, the interaction becomes smaller as the anion radius increases.

ESI-MS represents a versatile tool to evaluate both qualitatively and quantitatively binding properties in molecular recognition processes. ${ }^{21}$ In this work we carried out an ESI-MS study aimed to estimate the distinctive binding affinities of compound 1c towards different anions. A qualitative agreement between NMR titration experiments and ESI-MS data were found only when MeCN was used as the mobile phase using

Table 2 Binding constants for the interaction of $1 \mathrm{c}$ with different anions, as their TBA salts, determined by ${ }^{1} \mathrm{H} N M R$ in $5 \% \mathrm{D}_{2} \mathrm{O}$ in $\mathrm{CD}_{3} \mathrm{CN}$ at $500 \mathrm{MHz}$ and $303 \mathrm{~K}$

\begin{tabular}{lllll}
\hline \multirow{2}{*}{ Entry } & Anion & $\begin{array}{l}\log \beta^{a} \\
\text { (receptor-anion) }\end{array}$ & $K_{\mathrm{a}}$ & $\mathrm{BC}_{50}^{0}[\mathrm{mM}]$ \\
\hline 1 & $\mathrm{Cl}^{-}$ & $3.20 \pm 0.08(1: 1)^{b}$ & $1585(1: 1)$ & $(0.6 \pm 0.1)$ \\
& & $4.6 \pm 0.1(1: 2)^{c}$ & $25(1: 2)$ & \\
2 & $\mathrm{Br}^{-}$ & $2.20 \pm 0.02(1: 1)^{b}$ & $159(1: 1)$ & $(5.9 \pm 0.3)$ \\
& & $2.96 \pm 0.08(1: 2)^{c}$ & $6(1: 2)$ & \\
3 & $\mathrm{I}^{-}$ & $1.92 \pm 0.03(1: 1)^{b}$ & $83(1: 1)$ & $(11.2 \pm 0.2)$ \\
& & $2.5 \pm 0.1(1: 2)^{c}$ & $4(1: 2)$ & \\
4 & $\mathrm{NO}_{3}{ }^{-}$ & $1.95 \pm 0.04(1: 1)^{b}$ & $89(1: 1)$ & $(10.3 \pm 0.8)$ \\
& & $2.6 \pm 0.1(1: 2)^{c}$ & $5(1: 2)$ &
\end{tabular}

${ }^{a}$ Obtained by the simultaneous non-linear regression fitting of all the available ${ }^{1} \mathrm{H}$ NMR signals using the HypNMR program. ${ }^{b} \beta(1: 1)$ is defined as the formation constant for the $1: 1$ receptor/substrate complex in $\mathbf{M}^{-1}$. ${ }^{c}$ In this case $\beta(1: 2)$ is the cumulative formation constant for the corresponding $1: 2$ receptor/substrate complex in $\mathrm{M}^{-2}$. equimolar solutions $\left(1 \times 10^{-5} \mathrm{M}\right)$ of $[\mathbf{1 c}]\left(\mathrm{NTf}_{2}\right)_{2}$ and $(\mathrm{TEA}) \mathrm{Cl}$. We are aware that comparison of adducts with $\mathrm{Cl}^{-}$and $\mathrm{NTf}_{2}{ }^{-}$ certainly represents two extreme situations in terms of ion size and hydrophilic character; however, we envisage that for ion adducts displaying similar size, shape and properties, such as those comprising the $[\mathbf{1 c ~ X}]^{+}$adducts where $\mathrm{X}$ stands for $\mathrm{Cl}^{-}$, $\mathrm{Br}^{-} \mathrm{I}^{-}$and $\mathrm{NO}_{3}^{-}$anions, competitive ESI experiments might provide a good match between ion abundances in the ESI mass spectrum and solution concentration. To validate this hypothesis, we performed a competitive ESI mass analysis on an equimolar solution of $[\mathbf{1 c}]\left(\mathrm{NTf}_{2}\right)_{2}$ and TEAX $\left(\mathrm{X}=\mathrm{Cl}^{-}, \mathrm{Br}^{-}, \mathrm{I}^{-}\right.$ and $\mathrm{NO}_{3}{ }^{-}$) in MeCN (see Fig. 4). ${ }^{22}$

On the basis of the relative intensities from the ESI mass spectrum, and normalizing the ion abundances of $[1 \mathbf{c ~ C l}]^{+}$to $100 \%$, the corresponding adducts follow the trend $[1 \mathrm{c} \mathrm{Cl}]^{+}$ $(100)>[1 \mathrm{c} \mathrm{Br}]^{+}(37)>[1 \mathrm{c} \mathrm{NO}]^{+}(20)>[1 \mathrm{c} \mathrm{I}]^{+}(16)$ in qualitative agreement with the trend observed by NMR titration methods. We also detected a minor peak at $\mathrm{m} / \mathrm{z} 974$ that formally correspond to the $\left[1 \mathbf{c} \mathrm{Cl}_{2}+\mathrm{TEA}\right]^{+}$cation (marked in blue in Fig. 4). After diluting $\times 10$ and $\times 100$ the sample solutions, this species was still present, thus suggesting that adducts $\left[\mathbf{1 c}: \mathrm{Cl}_{2}\right]$ with a $1: 2$ stoichiometry are present in the solution rather than being formed due to non-specific interactions during the ESI process. ${ }^{23}$ It must be noted that the use of ESI-MS to estimate IL:anion interaction strengths based on (i) the propensity to aggregate into $\left[\mathrm{IL}_{x} \text { anion }_{(x-1)}\right]^{+}$in single stage ESI mass spectra or (ii) CID of mixed $\left[\mathrm{IL}_{1} \mathrm{IL}_{2} \mathrm{~A}\right]^{+}$adducts (the same applies for anions), is well-documented. ${ }^{24}$ However, in our particular case, single stage ESI mass spectra of 1c displayed poor aggregation. For example, for the ESI-MS of $\mathbf{1 c}$ in $\mathrm{MeCN}$, the $\left[\mathbf{1 c}_{2} \text { anion }_{3}\right]^{+}$or the $\left[\mathbf{1 c a n i o n}_{3}\right]^{-}$ions were barely detected, and accordingly the methodology based on (i) and (ii) criterions could not be satisfactorily applied.

\section{Theoretical studies}

According with the predominant 1:1 host-guest complex observed in solution by ${ }^{1} \mathrm{H}$ NMR and ESI-MS, theoretical calculations were carried out at the B3LYP/6-31G(d,p) level to predict the structure of the positively charged receptor-anion complexes when considering the interaction with only one chloride anion. Since the supramolecular complexes can display certain flexibility in solution, we subjected the

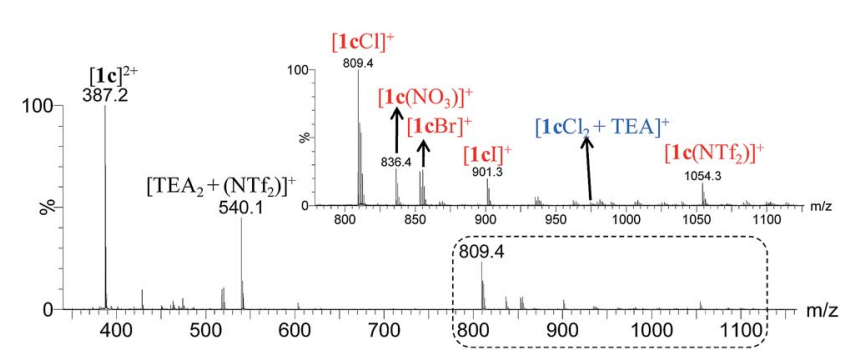

Fig. 4 Competitive ESI mass spectrum of an equimolar mixture of [1c] $\left(\mathrm{NTf}_{2}\right)_{2}$ and TEAX, $\left(\mathrm{X}=\mathrm{Cl}^{-}, \mathrm{Br}^{-}, \mathrm{I}^{-}\right.$and $\left.\mathrm{NO}_{3}{ }^{-}\right)$in $\mathrm{MeCN}$. The inset shows the expanded region in the $\mathrm{m} / \mathrm{z} 750-1150$ range illustrating the ion abundances of the species $[1 \mathrm{c} \mathrm{X}]^{+}$. 
corresponding host-guest structures to Monte Carlo conformational searches without restrictions followed by MMFF minimizations, in order to fully map all the possible conformations and anion-cation relative dispositions. To this aim, 10000 structures were stochastically generated and minimized with the MMFF molecular force field using the Monte Carlo conformational search available in Spartan'14. ${ }^{25}$ Then, the lowest 100 minima were analysed and ordered attending to their relative energies. The resulting minimum energy conformer was optimized at the B3LYP/6-31+G* level of theory using the Gaussian 09 software,$^{26}$ being the corresponding global minima shown in Fig. 5 for a $1: 1$ model complex and in Fig. 6 for the corresponding dichloride salts of 1a-c. For $1: 1$ complexes, the dicationic bis(imidazolium) salt with methyl substituents $\left(\mathrm{R}=\mathrm{R}^{1}=\mathrm{CH}_{3}\right)$ was used as a model compound to simplify the high level calculations. The global minima optimized structure is illustrated in Fig. 5 and shows the ability of this receptor to form a very stable complex displaying multiple $\mathrm{H}$-bonding interactions. In this $1: 1$ structure the receptor can efficiently fold over the chloride anion in such a way that the anion is able to form strong hydrogen bonds with the acidic hydrogen atoms of the receptor and be shielded from the influence of the solvent. In this case, the chloride anion is hydrogen bonded, simultaneously, to the hydrogen atoms of both amide $\mathrm{NH}$ groups and the two Ha atoms of the imidazolium rings. The anion is also at short distances from both $\mathrm{Hd}$ atoms and from $\mathrm{He}$. The calculated $\mathrm{Cl} \cdots \mathrm{H}$ distances are in very good agreement with the trends observed for $\Delta \delta$ values in ${ }^{1} \mathrm{H}$ NMR upon addition of TBACl. For Hd the observed shift in the corresponding signals is similar to that observed for Ha in NMR experiments ( $c a .0 .6 \mathrm{ppm}$ ) although the calculated distance to the anion is larger, but in this case it must be taken into consideration that the effect of the interaction of chloride with Ha also affects to the shifts of the other two imidazolium hydrogen atoms $\mathrm{Hb}$ and $\mathrm{Hd}(\Delta \delta$ values $\approx 0.17 \mathrm{ppm}$, similar to those for $\mathrm{He}$ ).

We carried out also simple molecular modelling calculations for the $1: 2$ complexes and in this case we considered the full

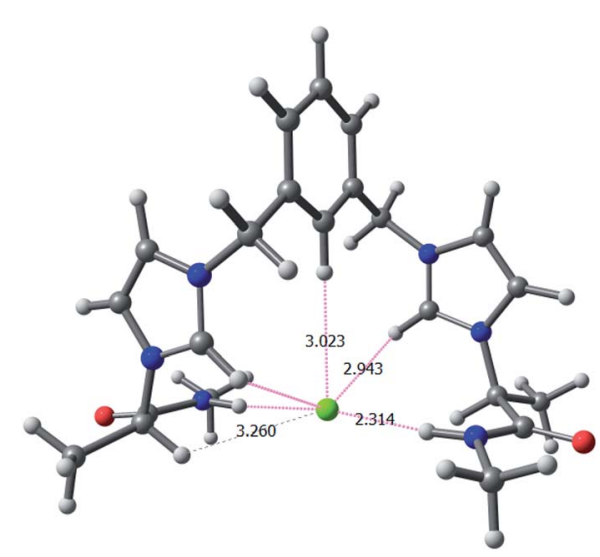

Fig. 5 Global minima optimized structure for the supramolecular $1: 1$ complex formed between dicationic bis(imidazolium) salt with methyl substituents $\left(\mathrm{R}=\mathrm{R}^{\prime}=\mathrm{CH}_{3}\right)$ and $\mathrm{Cl}^{-}$.

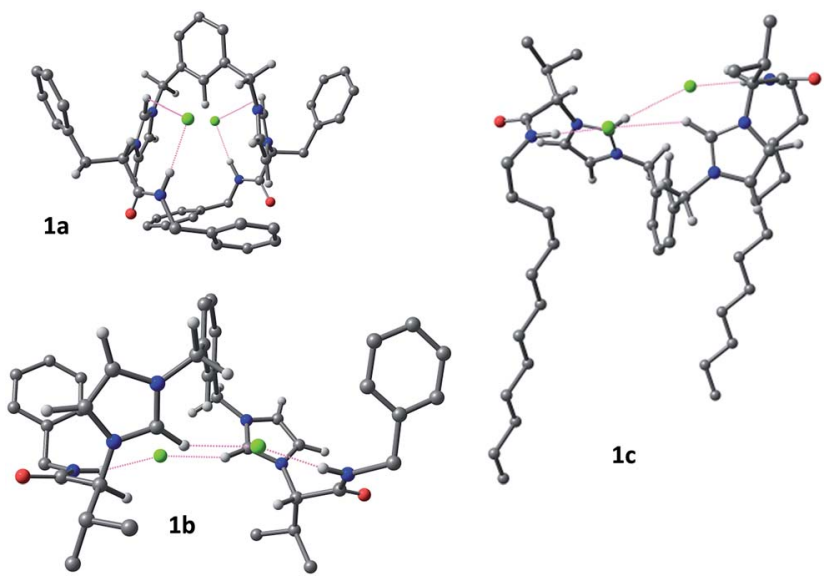

Fig. 6 Global minima optimized structures for the supramolecular complexes formed between bis(imidazolium) cations $1 \mathrm{a}-\mathrm{c}$ and two $\mathrm{Cl}^{-}$anions. For clarity, we only show the polar hydrogen atoms implicated in $\mathrm{H}$-bonding interactions (shown as red dashed lines).

set of structural parameters to analyse their effects and to rationalize the experimental data for chloride binding.

The minima display different conformations with a different connectivity of $\mathrm{H}$-bonds implicating the chloride anions. For dication 1a, the receptor adopts a cleft conformation in which the $N$-benzyl groups are located closing the gate of the cleft. This geometry is stabilized by a number of electrostatic $\mathrm{H}$-bonds between the chloride anions and the acidic hydrogens of the receptor. In this regard, each chloride anion is $\mathrm{H}$-bonded to the hydrogen of one amide $\mathrm{NH}$ group and to one imidazolium $\mathrm{Ha}$, with two eight membered chelated rings, being formed at each pseudopeptidic chain. However, for $\mathbf{1 b}$ and $\mathbf{1 c}$ the receptor adopts a cleft conformation in which the N-substituents do not close the cleft gate but are folded backwards. In this case, the intramolecular H-bonds involve each chloride anion with the amide hydrogen of one of the chains and the imidazolium Ha of the other chain. The observed conformations correlate well with the ${ }^{1} \mathrm{H}$ NMR shifts observed during the titration experiments. The calculated H-bond distances are shown in Table 3. Again, although the $\mathrm{NH}$-anion distances are the shortest ones, very short distances are observed from the chloride to other hydrogen atoms, besides the imidazolium $\mathrm{Ha}$, like $\mathrm{Hd}$, $\mathrm{He}$ and $\mathrm{Hf}$.

\section{Chloride transport studies}

The complexation properties of these receptors prompted us to study them as transport agents across lipid bilayer membranes, in particular for a biologically very relevant species like chloride.

Table $3 \mathrm{Cl}-\mathrm{H}$ distances $(\AA ̊)$ for the optimized structures ${ }^{a}$

\begin{tabular}{lllllll}
\hline Entry & Receptor & NH-Cl & Ha-Cl & Hd-Cl & He-Cl & Hf-Cl \\
\hline 1 & 1a & 2.207 & 2.962 & 2.554 & 3.291 & 2.683 \\
2 & 1b & 2.151 & 2.950 & 2.595 & 2.624 & 2.695 \\
3 & 1c & 2.206 & 2.930 & 2.569 & 2.831 & 2.718
\end{tabular}

${ }^{a}$ Calculated for the bis(imidazolium) cations $\mathbf{1 a}-\mathbf{c}$ and two $\mathrm{Cl}^{-}$anions. 
Table 4 Binding constants for the interaction with $\mathrm{NO}_{3}{ }^{-}$as its TBA salt determined by ${ }^{1} \mathrm{H}$ NMR in $5 \% \mathrm{D}_{2} \mathrm{O}$ in $\mathrm{CD}_{3} \mathrm{CN}$ at $500 \mathrm{MHz}$ and $303 \mathrm{~K}$

\begin{tabular}{llllr}
\hline Entry & Receptor & $\begin{array}{l}\log \beta^{a} \\
\text { (receptor-anion) }\end{array}$ & $K_{\mathrm{a}}$ & $\mathrm{BC}_{50}^{0}[\mathrm{mM}]$ \\
\hline 1 & \multirow{2}{*}{ 1a } & $2.05 \pm 0.02(1: 1)^{b}$ & $113(1: 1)$ & $(8.9 \pm 0.4)$ \\
& & $2.65 \pm 0.06(1: 2)^{c}$ & $4(1: 2)$ & \\
2 & 1b & $1.78 \pm 0.03(1: 1)^{b}$ & $61(1: 1)$ & $(16.5 \pm 0.9)$ \\
& & $2.2 \pm 0.1(1: 2)^{c}$ & $2(1: 2)$ & \\
3 & 1c & $1.95 \pm 0.04(1: 1)^{b}$ & $89(1: 1)$ & $(10.3 \pm 0.8)$ \\
& & $2.6 \pm 0.1(1: 2)^{c}$ & $5(1: 2)$ &
\end{tabular}

${ }^{a}$ Obtained by simultaneous non-linear regression fitting of all the available ${ }^{1} \mathrm{H}$ NMR signals. ${ }^{b} \beta(1: 1)$ is defined as the formation constant for the $1: 1$ receptor/substrate complex in $\mathrm{M}^{-1} .{ }^{c}$ In this case $\beta(1: 2)$ is the cumulative formation constant for the corresponding $1: 2$ receptor/substrate complex in $\mathrm{M}^{-2}$.

Since transmembrane transport experiments were carried out in the presence of nitrate, ${ }^{1} \mathrm{H}$ NMR anion-binding studies were also conducted for receptors $\mathbf{1 b}$-c with nitrate anions (Table 4) in order to provide the appropriate basic data for chloride transport studies. The corresponding stability constants, $K_{\mathrm{a}}$, were determined again by following the shift of the ${ }^{1} \mathrm{H}$ NMR signals of five protons from the receptor and fitting the data to $1: 1$ and $1: 2$ receptor : anion binding isotherms using HypNMR. As is shown by the data gathered in Table 4 , the receptors interact weakly with nitrate anions, displaying stability constants lower than 113 $\mathbf{M}^{-1}$. For receptors $\mathbf{1 b}$ and $\mathbf{1 c}$ a good selectivity for chloride is observed as reflected in the $\mathrm{BC}_{50}^{0}$ values $(5.0$ vs. 16.5 for $\mathbf{1 b}$ and $0.6 v s .10 .3$ for 1c), while the selectivity is smaller for the receptor 1a (6.7 vs. 8.9 for $\mathrm{BC}_{50}^{0}$ values).

The transmembrane anion transport properties of receptors 1a, 1b and 1c were explored using vesicle based methods. ${ }^{27}$ Unilamellar POPC vesicles encapsulating $488 \mathrm{mM} \mathrm{NaCl}$ buffered to $\mathrm{pH} 7.2$ with $5 \mathrm{mM}$ sodium phosphate salts were suspended in an isotonic $\mathrm{NaNO}_{3}$ solution. The studied compounds

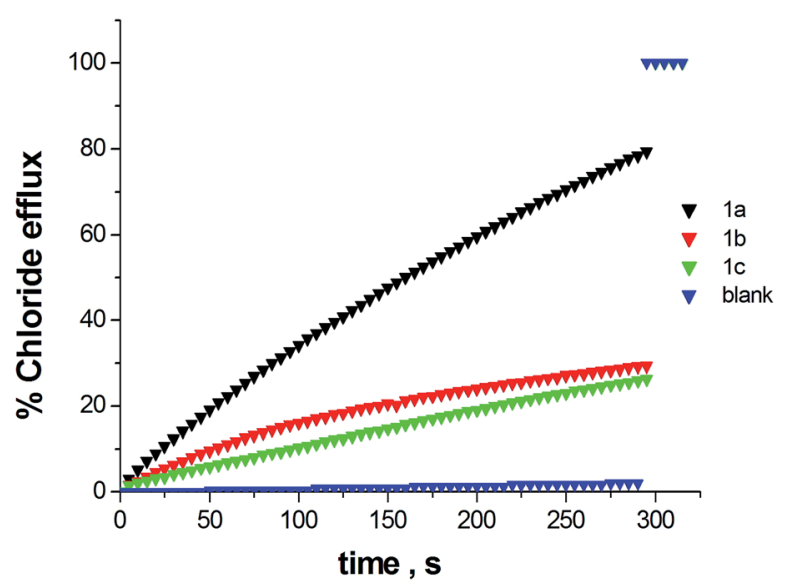

Fig. 7 Chloride efflux promoted by compounds $1 \mathrm{a}-\mathrm{c}(75 \mu \mathrm{M}, 15 \% \mathrm{~mol}$ carrier to lipid concentration) in unilamellar POPC vesicles. Vesicles loaded with $489 \mathrm{mM} \mathrm{NaCl}$ buffered at $\mathrm{pH} 7.2$ with $5 \mathrm{mM}$ phosphate dispersed in $489 \mathrm{mM} \mathrm{NaNO}_{3}$ buffered at $\mathrm{pH}$ 7.2. Each trace represents the average of at least different three trials. were added as DMSO solutions using a minimal amount of solvent to avoid disturbance of the liposomes. The chloride efflux from the interior of the vesicles was monitored using a chloride ion selective electrode (ISE). After a fixed time (300 s) detergent was added to lyse the vesicles and induce the efflux of all encapsulated chloride. The final electrode reading was used to calibrate the $100 \%$ chloride release. The chloride efflux induced by compounds 1a-c (15\% molar carrier to phospholipid loading) is shown in Fig. 7. Under these conditions compound 1a showed a good activity whereas $\mathbf{1 b}$ and $\mathbf{1 c}$ induced a more modest chloride efflux. By carrying out a Hill analysis of the chloride efflux induced by $\mathbf{1 a}$ at different concentrations, an $\mathrm{EC}_{50}$ value of $10.5 \%$ molar 1a:POPC was calculated (see Fig. S35 and S36†). ${ }^{28} \mathrm{EC}_{50}$ is defined as the concentration needed for releasing $50 \%$ of encapsulated chloride under the conditions described above for this assay. The Hill parameter was found at 3.8 suggesting cooperativity in the transport activity exerted by $\mathbf{1 a}$. It can be seen that the receptor with a lower chloride affinity presents the higher transport activity. This is not surprising as transmembrane ion transport is an extremely complicated process involving many equilibria and several steps and thus, the affinity for the guest is not the single parameter determining the transport efficiency. ${ }^{29}$ In this regard, for instance, differences in lipophilicity (1c presents high lipophilicity) can be as important as those in binding constants. The transport activity is defined by a delicate balance between different parameters for which binding constants in different solvent media and lipophilicity are just two of the involved parameters.

In order to investigate the impact of the external anion in the chloride release mediated by the receptors, another set of experiments using POPC vesicles containing $451 \mathrm{mM} \mathrm{NaCl}$ buffered to $\mathrm{pH} 7.2$ with $20 \mathrm{mM}$ sodium phosphate salts suspended in $150 \mathrm{mM} \mathrm{Na}_{2} \mathrm{SO}_{4}$ buffered to $\mathrm{pH} 7.2$ was performed. The results are shown in Fig. 8. Under these conditions chloride efflux promoted by 1a was greatly reduced whereas the

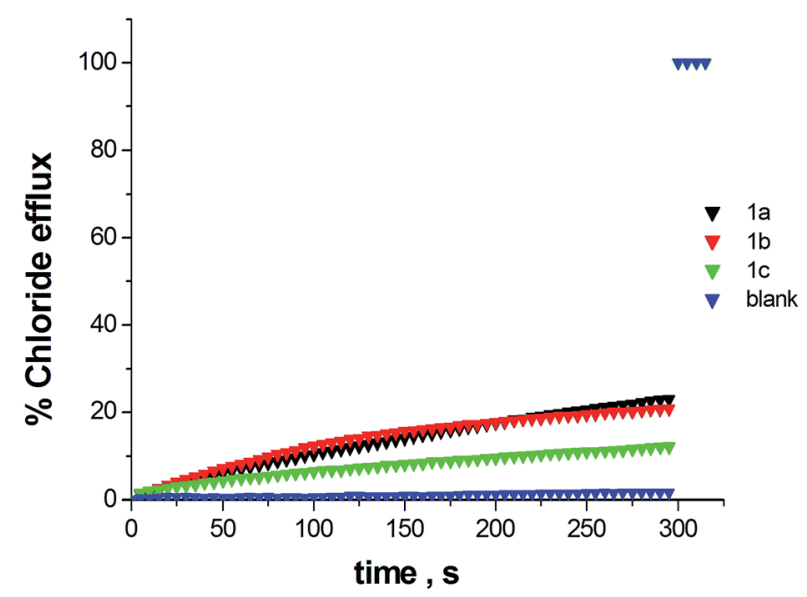

Fig. 8 Chloride efflux promoted by compounds $1 \mathrm{a}-\mathrm{c}(75 \mu \mathrm{M}, 15 \% \mathrm{~mol}$ carrier to lipid concentration) in unilamellar POPC vesicles. Vesicles loaded with $450 \mathrm{mM} \mathrm{NaCl}$ buffered at $\mathrm{pH} 7.2$ with $20 \mathrm{mM}$ phosphate dispersed in $150 \mathrm{mM} \mathrm{Na}_{2} \mathrm{SO}_{4}$ buffered at $\mathrm{pH}$ 7.2. Each trace represents the average of at least different three trials. 


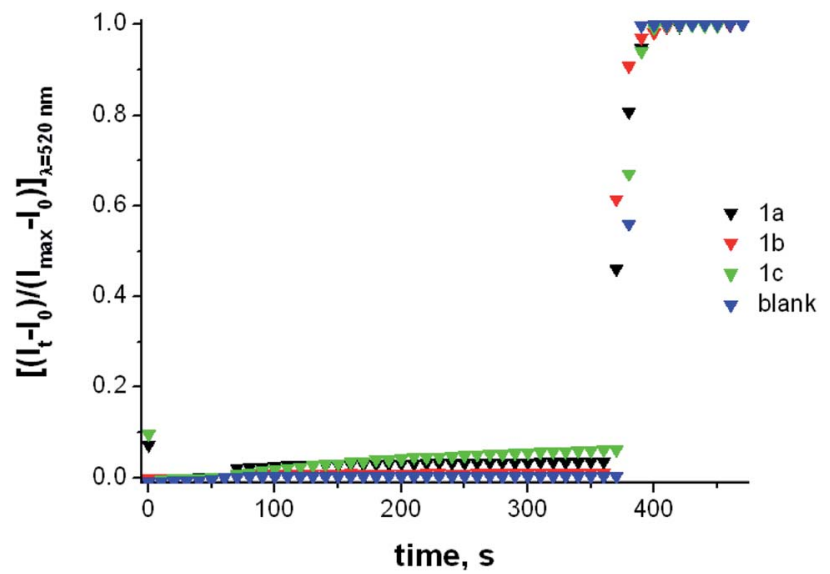

Fig. 9 CF leakage induced by $1 \mathrm{a}-\mathrm{c}(15 \% \mathrm{~mol}$ carrier to lipid) from unilamellar POPC vesicles (0.05 mM) loaded with $50 \mathrm{mM} \mathrm{CF}$ and 451 $\mathrm{mM} \mathrm{NaCl}$, buffered to $\mathrm{pH} 7.2$ with $20 \mathrm{mM}$ sodium phosphate salts. The vesicles were suspended in $150 \mathrm{mM} \mathrm{Na}_{2} \mathrm{SO}_{4}$ buffered to $\mathrm{pH} 7.2$ with 20 $\mathrm{mM}$ sodium phosphate salts. At $t=60 \mathrm{~s}$, a DMSO solution of the transporter was added to start the experiment. At the end of the experiment $(t=360 \mathrm{~s})$, detergent was added to lyse the vesicles and induce the release of all encapsulated CF.

transmembrane transport activity observed for $\mathbf{1 b}$ and $\mathbf{1 c}$ was essentially maintained. These results could indicate that anion exchange mechanism is dominant in the case of receptor 1a. Thus chloride efflux is more efficient in the presence of nitrate, a relatively lipophilic anion, whereas the high hydrophilicity of the $\mathrm{SO}_{4}{ }^{2-}$ anion makes its transport much more difficult reducing the overall transport activity.

Further experiments to investigate the transmembrane transport activity of these receptors were performed using fluorescence based assays. We decided to use the 5(6)-carboxyfluorescein leakage test. $^{30}$ Carboxyfluorescein (CF) is selfquenching at high concentration. Thus, if CF is encapsulated at high concentrations in the interior of the liposomes, little fluorescence is detected. On the other hand, leakage of entrapped CF into the much larger volume of the cuvette is readily signalled by the characteristic highly fluorescence of the diluted CF solutions. CF is a membrane impermeable dye and thus CF release from the interior of the vesicle is indicative of disruption of the membrane integrity or formation of membrane pores large enough to allow the leaking of this anion. The CF leakage test was performed on vesicles containing $\mathrm{CF}$ and $\mathrm{NaCl}$, dispersed in a $\mathrm{Na}_{2} \mathrm{SO}_{4}$ solution (Fig. 9). Illustrative results are shown in Fig. S40-S46. $\dagger$ No indications of leakage were observed. After addition of compounds 1a-c very little fluorescence was detected prior to the addition of detergent to the vesicle suspension. These results ruled out the possibility of an unspecific detergent action exerted by these derivatives.

\section{Conclusions}

The results here presented demonstrate that bis(imidazolium) salts can be selective, when properly designed, for the binding of chloride anion in solution as analysed by NMR spectroscopy and ESI-MS. ${ }^{1} \mathrm{H}$ NMR titration experiments reveal that compound 1c shows binding constants more than two orders of magnitude larger for chloride than for any other halide or anion studied. The binding affinities of $\mathbf{1 c}$ with different anions were also investigated by competitive ESI-MS experiments. Qualitative agreement between binding affinities estimated by ESI-MS and NMR data was found by considering the relative abundances of the $1: 1$ adducts $[1 \mathrm{c} \mathrm{X}]^{+}\left(\mathrm{X}=\mathrm{Cl}^{-}, \mathrm{Br}^{-}, \mathrm{I}^{-}\right.$and $\left.\mathrm{NO}_{3}{ }^{-}\right)$. In order to establish a proper correlation between ESI-MS and NMR experiments, several experimental factors need to be considered: (i) the selection of acetonitrile as the solvent is important to minimize the distinctive effect of the surface activity of the anions, following recent observations from McInode's group on closely related IL's; ${ }^{22}$ (ii) because of the large size of 1c, the dominant effect manifested in the individual ion abundances for the observed $[1 \mathrm{c} \mathrm{X}]^{+}\left(\mathrm{X}=\mathrm{Cl}^{-}, \mathrm{Br}^{-}, \mathrm{I}^{-}\right.$ and $\mathrm{NO}_{3}^{-}$) cations must be the binding energy rather than surface activity differences. Regarding the transmembrane chloride transport studies, compound 1a posses a reasonable activity, favouring the transport via an exchange mechanism, while compounds $\mathbf{1 b - c}$ display a low level of chloride transport activity. Importantly, these derivatives do not exert an unspecific detergent action in the lipid bilayer. Although the level of activity found for these compounds is yet far from optimal, the tunability of the design holds promise for developing improved transmembrane transporters based on ionic liquids derived from aminoacids.

\section{Experimental}

\section{General}

Reagents and solvents were purchased from commercial suppliers (Aldrich, Fluka or Merck) and were used without further purification.

\section{NMR spectroscopy}

The NMR experiments were carried out on a Varian INOVA 500 spectrometer (500 MHz for ${ }^{1} \mathrm{H}$ and $125 \mathrm{MHz}$ for ${ }^{13} \mathrm{C}$ ). Chemical shifts are reported in ppm by using TMS as a reference. Titration experiments followed by ${ }^{1} \mathrm{H}$ NMR spectroscopy were performed in $\mathrm{CD}_{3} \mathrm{CN} / \mathrm{D}_{2} \mathrm{O} 95: 5$ at $303 \mathrm{~K}$ and data fitting was carried out with the HypNMR 2008 version 4.0.71 software.

\section{Molecular modelling}

The supramolecular complexes between 1a-c and the guests were generated manually and submitted to conformational analysis by Monte Carlo conformational searches as implemented in Spartan'14 software. To this aim, 10000 structures were stochastically generated and minimized with the MMFF molecular force field. Then, the lowest 100 minima were analysed and ordered attending to their relative energies. Different starting geometries and anion-cation dispositions were used in order to verify that the systems converged to the same final minima. The obtained minima were subsequently fully minimized at the B3LYP/6-31G(d,p) level of theory. The stationary 
points have been characterized as true minima by the calculation of the normal vibration modes, being all the values positive.

\section{Membrane transport assays}

Preparation of phospholipid vesicles. A chloroform solution (20 mg mL ${ }^{-1}$ ) of 1-palmitoyl-2-oleoyl-sn-glycero-3-phosphocholine (POPC) (Sigma-Aldrich) was evaporated in vacuo using a rotary evaporator. The lipid film thus obtained was dried under high vacuum for at least 4 hours and then it was rehydrated by addition of a sodium chloride solution ( $489 \mathrm{mM} \mathrm{NaCl}$ and $5 \mathrm{mM}$ phosphate buffer, $\mathrm{pH}$ 7.2) followed by vortexing. The lipid suspension was then subjected to nine freeze-thaw cycles and twenty-nine extrusions through a $200 \mathrm{~nm}$ polycarbonate Nucleopore membrane using a LiposoFast Basic extruder (Avestin, Inc.). The resulting unilamellar vesicles were dialyzed against a $\mathrm{NaNO}_{3}$ solution $\left(489 \mathrm{mM} \mathrm{NaNO}_{3}\right.$ and $5 \mathrm{mM}$ phosphate buffer, pH 7.2) or $\mathrm{Na}_{2} \mathrm{SO}_{4}$ solution $\left(150 \mathrm{mM} \mathrm{Na}_{2} \mathrm{SO}_{4}\right.$ and $20 \mathrm{mM}$ phosphate buffer, $\mathrm{pH}$ 7.2) to remove unencapsulated chloride.

\section{Ion selective electrode (ISE) transport assays}

Chloride/nitrate transport assays. Unilamellar POPC vesicles containing $\mathrm{NaCl}$ (prepared as described above) were suspended in a $489 \mathrm{mM} \mathrm{NaNO}$ solution buffered to $\mathrm{pH} 7.2$ with sodium phosphate salts ( $5 \mathrm{mM}$ buffer). The final lipid concentration per sample was $0.5 \mathrm{mM}$ and the total volume of $5 \mathrm{~mL}$. A DMSO solution of the carrier molecule, typically $10-20 \mu \mathrm{L}$ to avoid the influence of the solvent molecule in the assay, was added and the chloride release out of vesicles was monitored using a chloride selective electrode for 5 minutes. Then, the vesicles were lysed by adding $40 \mu \mathrm{L}$ of Triton-X (10\% dispersion in water). The initial value was set at $0 \%$ chloride efflux and the final one was set as $100 \%$ chloride efflux. All other data were calibrated to these points. All traces represent an average of at least three independent experiments.

\section{Ion selective electrode (ISE) transport assays}

Chloride/sulfate transport assays. The experiments were conducted as described above using unilamellar POPC vesicles (100 nm mean diameter) containing an encapsulated solution of $451 \mathrm{mM} \mathrm{NaCl}$ and $20 \mathrm{mM}$ phosphate buffer, $\mathrm{pH} 7.2$, were suspended in a solution $150 \mathrm{mM} \mathrm{Na} \mathrm{SO}_{4}$ and $20 \mathrm{mM}$ phosphate buffer, $\mathrm{pH}$ 7.2, for a final lipid concentration of $0.5 \mathrm{mM}$ and a total volume of $5 \mathrm{~mL}$. All traces represent an average of at least three independent experiments.

Fluorescence assays. $200 \mathrm{~nm}$ unilamellar vesicles encapsulating 5(6)-carboxyfluorescein (CF) dissolved in a sodium chloride solution (451 $\mathrm{mM} \mathrm{NaCl}, 50 \mathrm{mM} 5$ (6)-carboxyfluorescein (CF), $20 \mathrm{mM}$ phosphate buffer at $\mathrm{pH} 7.2$ ) were prepared as described above. Unencapsulated 5(6)-carboxyfluorescein was removed by size exclusion chromatography on a Sephadex G-50 column using a sodium sulfate solution as eluent $(150 \mathrm{mM}$ $\mathrm{Na}_{2} \mathrm{SO}_{4}, 20 \mathrm{mM}$ phosphate buffer at $\mathrm{pH}$ 7.2). The vesicles were suspended in a solution of $150 \mathrm{mM} \mathrm{Na} \mathrm{SO}_{4}$ and $20 \mathrm{mM}$ phosphate buffer, pH 7.2 for a final lipid concentration of $0.025 \mathrm{mM}$ or $0.05 \mathrm{mM}$.
The fluorescence emission of the vesicle suspension $(2.5 \mathrm{~mL}$ samples) at $520 \mathrm{~nm}$ after excitation at $490 \mathrm{~nm}$ was recorded for 8 minutes (a measure every 10 seconds under continuous stirring) using a HITACHI F-7000 Fluorescence spectrophotometer. At $t=60 \mathrm{~s}$, a solution of the carrier molecule in DMSO (15\% molar carrier to lipid) was added. At the end of the experiment $(t=360 \mathrm{~s})$ the vesicles were lysed by addition of detergent ( $20 \mu \mathrm{L}$ of Triton-X (10\% dispersion in water)). The extent of the CF leakage from the interior of the vesicles can be estimated from the variation of the fluorescence intensity.

$$
\text { CF leakage }=\left[\frac{I_{t}-I_{0}}{I_{\max }-I_{0}}\right]_{\lambda=520 \mathrm{~nm}}
$$

$I_{0}=$ fluorescence intensity at time $0, I_{t}=$ fluorescence intensity at time $t, I_{\max }=$ maximum fluorescence intensity observed after addition of detergent.

\section{Acknowledgements}

Financial support from Ministerio de Economía y Competitividad (CTQ2011-28903-C02-01), Generalitat Valenciana (PROMETEO 2012/020) and Universitat Jaume I (P11B2013-38), Consejería de Educación de la Junta de Castilla y León (Project BU340U13) and Fundació la Maratón de TV3 is acknowledged.

\section{Notes and references}

1 Anion receptors: (a) J. L. Sessler, P. A. Gale and W.-S. Cho, Anion Receptor Chemistry, RSC, Cambridge, 2006; (b) F. P. Schmidtchen and M. Berger, Chem. Rev., 1997, 97, 1609; (c) P. D. Beer and P. A. Gale, Angew. Chem., Int. Ed., 2001, 40, 486; (d) R. Martínez-Manez and F. Sancenon, Chem. Rev., 2003, 103, 4419; (e) P. A. Gale, Coord. Chem. Rev., 2003, 240, 1; (f) P. A. Gale and R. Quesada, Coord. Chem. Rev., 2006, 250, 3219; (g) P. A. Gale, S. E. GarcíaGarrido and J. Garric, Chem. Soc. Rev., 2008, 37, 151; (h) C. Caltagirone and P. A. Gale, Chem. Soc. Rev., 2009, 38, 520; (i) M. Cametti and K. Rissanen, Chem. Commun., 2009, 2809; (j) N. H. Evans and P. D. Beer, Angew. Chem., Int. Ed, 2014, 53, 11716.

2 (a) J. L. Sessler, P. A. Gale and W. S. Cho, Anion Receptor Chemistry, RSC Publishing, Cambridge, 2006; (b) Supramolecular Chemistry of Anions, ed. A. Bianchi, K. Bowman-James and E. García-España, Wiley-VCH, Weinheim, 1997; (c) A. B. P. Lever and P. A. Gale, Special Issue: Anion Coordination Chemistry II, Coord. Chem. Rev., 2006, 250, 2917.

3 (a) M. Wenzel, J. R. Hiscock and P. A. Gale, Chem. Soc. Rev., 2012, 41, 480; (b) A. P. Davis, D. N. Sheppard and B. D. Smith, Chem. Soc. Rev., 2007, 36, 348.

4 (a) H. T. Chifotides, I. D. Giles and K. R. Dunbar, J. Am. Chem. Soc., 2013, 135, 3039; (b) L. Trembleau, T. A. D. Smith and M. H. Abdelrahman, Chem. Commun., 2013, 49, 5850; (c) A. Basu and G. Das, Chem. Commun., 2013, 49, 3997; (d) E. García-España, P. Díaz, J. M. Llinares and A. Bianchi, Coord. Chem. Rev., 2006, 250, 2952. 
5 (a) J. Yoon, S. K. Kim, N. J. Singh and K. S. Kim, Chem. Soc. Rev., 2006, 35, 355; (b) Z. Xu, S. K. Kim and J. Yoon, Chem. Soc. Rev., 2010, 39, 1457; (c) Q.-S. Lu, L. Dong, J. Zhang, J. Li, L. Jiang, Y. Huang, S. Qin, C.-W. Hu and X.-Q. Yu, Org. Lett., 2009, 11, 669.

6 (a) A. H. Flood, Y. Liu and J. F. Stoddart, in Modern Cyclophane Chemistry, ed. R. Gleiter and H. Hopf, WileyVCH, Weinheim, 2004; (b) Y. Yuan, G. Gao, Z.-L. Jiang, J.-S. You, Z.-Y. Zhou, D.-Q. Yuan and R.-G. Xie, Tetrahedron, 2002, 58, 8993; (c) J. Yoon, S. K. Kim, N. J. Singh, J. W. Lee, Y. J. Yang, K. Chellappan and K. S. Kim, J. Org. Chem., 2004, 69, 581; (d) P. P. Neelakandan, M. Hariharan and D. Ramaiah, Org. Lett., 2005, 7, 5765; (e) P. P. Neelakandan, M. Hariharan and D. Ramaiah, J. Am. Chem. Soc., 2006, 128, 11334; $(f)$ P. P. Neelakandan and D. Ramaiah, Angew. Chem., Int. Ed., 2008, 47, 8407; $(g)$ V. K. Khatri, S. Upreti and P. S. Pandey, Org. Lett., 2006, 8, 1755; (h) V. K. Khatri, M. Chahar, K. Pavani and P. S. Pandey, J. Org. Chem., 2007, 72, 10224.

7 (a) P. A. Gale, P. Anzenbacher and J. L. Sessler, Coord. Chem. Rev., 2002, 222, 57; (b) M. D. Best, S. L. Tobey and E. V. Anslyn, Coord. Chem. Rev., 2003, 240, 3; (c) J. M. Llinares, D. Powell and K. Bowman-James, Coord. Chem. Rev., 2003, 240, 57; (d) C. R. Bondy and S. J. Loeb, Coord. Chem. Rev., 2003, 240, 77; (e) P. Anzenbacher, R. Nishiyabu and M. A. Palacios, Coord. Chem. Rev., 2006, 250, 2929; $(f)$ S. O. Kang, M. A. Hossain and K. BowmanJames, Coord. Chem. Rev., 2006, 250, 3038; $(g)$ C. Schmuck, Coord. Chem. Rev., 2006, 250, 3053.

8 H. Ihm, S. Yun, H. G. Kim, J. K. Kim and K. S. Kim, Org. Lett., 2002, 4, 2897.

9 (a) B. Hille, Ionic Channels of Excitable Membranes, Sinauer Associates, Sunderland, 3rd edn, 2001; (b) J. T. Davis, O. Okunola and R. Quesada, Chem. Soc. Rev., 2010, 39, 3843.

10 (a) F. M. Ashcroft, Nature, 2006, 440, 440; (b) F. M. Ashcroft, Ion Channels and Disease, Academic Press, San Diego, CA, 2000.

11 (a) S. Hussain, P. R. Brotherhood, L. W. Judd and A. P. Davis, J. Am. Chem. Soc., 2011, 133, 1614; (b) S. J. Moore, M. Wenzel, M. E. Light, R. Morley, S. J. Bradberry, P. Gomez-Iglesias, V. Soto-Cerrato, R. Perez-Tomas and P. A. Gale, Chem. Sci., 2012, 3, 2501; (c) S. Rastogi, E. Marchal, I. Uddin, B. Groves, J. Colpitts, S. A. McFarland, J. T. Davis and A. Thompson, Org. Biomol. Chem., 2013, 11, 3834; (d) L. E. Karagiannidis, C. J. E. Haynes, K. J. Holder, I. L. Kirby, S. J. Moore, N. J. Wells and P. A. Gale, Chem. Commun., 2014, 50, 12050.

12 (a) P. A. Gale, R. Pérez-Tomás and R. Quesada, Acc. Chem. Res., 2013, 56, 2801; (b) I. Alfonso and R. Quesada, Chem. Sci., 2013, 4, 3009; (c) N. Busschaert and P. A. Gale, Angew. Chem., Int. Ed., 2013, 52, 1374; (d) S.-K. Ko, S. K. Kim, A. Share, V. M. Lynch, J. Park, W. Namkung, W. Van Rossom, N. Busschaert, P. A. Gale, J. L. Sessler and I. Shin, Nat. Chem., 2014, 6, 885.

13 E. B. Anderson and T. E. Long, Polymer, 2010, 51, 2447.

14 P. A. Gale, J. Garric, M. E. Light, B. A. McNally and B. D. Smith, Chem. Commun., 2007, 1736.
15 (a) C.-R. Elie, N. Noujeim, C. Pardin and A. R. Schmitzer, Chem. Commun., 2011, 47, 1788; (b) C.-R. Elie, M. Charbonneau and A. R. Schmitzer, MedChemComm, 2012, 3, 1231; (c) M. Vidal and A. Schmitzer, Chem.-Eur. J., 2014, 20, 9998.

16 (a) L. González, J. Escorihuela, B. Altava, M. I. Burguete and S. V. Luis, Eur. J. Org. Chem., 2014, 5356; (b) L. González, B. Altava, M. Bolte, M. I. Burguete, E. García-Verdugo and S. V. Luis, Eur. J. Org. Chem., 2012, 4996; (c) B. Altava, D. S. Barbosa, M. I. Isabel Burguete, J. Escorihuela and S. V. Luis, Tetrahedron: Asymmetry, 2009, 2, 999.

17 L. González-Mendoza, J. Escorihuela, B. Altava, M. I. Burguete and S. V. Luis, Org. Biomol. Chem., 2015, DOI: 10.1039/c5ob00348b.

18 (a) V. M. S. Gil and N. C. Oliveira, J. Chem. Educ., 1990, 67, 473; (b) P. Job, Ann. Chim., 1928, 9, 113.

19 (a) C. Frassineti, L. Alderighi, P. Gans, A. Sabatini, A. Vacca and S. Ghelli, Anal. Bioanal. Chem., 2003, 376, 1041; (b) C. Frassineti, S. Ghelli, P. Gans, A. Sabatini, M. S. Moruzzi and A. Vacca, Anal. Biochem., 1995, 231, 374.

20 (a) A. Vacca, O. Francesconi and S. Roelens, Chem. Rec., 2012, 12, 544; (b) C. Nativi, O. Francesconi, G. Gabrielli, A. Vacca and S. Roelens, Chem.-Eur. J., 2011, 17, 4814; (c) S. Roelens, A. Vacca and C. Venturi, Chem.-Eur. J., 2009, 15, 2635; (d) S. Roelens, A. Vacca, O. Francesconi and C. Venturi, Chem.-Eur. J., 2009, 15, 8296.

21 J. M. Daniel, S. Friess, S. D. Rajagopalan, S. Wendt and R. Zenobi, Int. J. Mass Spectrom., 2002, 216, 1.

22 As identified by McIndoe in previous works on dicationic IL's, the use of MeCN as the mobile solvent provides a convenient solvent in which the effect of the distinctive polarity of ions is virtually equalized; see (a) Z. Fei, D.-R. Zhu, N. Yan, R. Scopelliti, S. A. Katsuba, G. Laurenczy, D. M. Chisholm, J. S. McIndoe, K. R. Seddon and P. J. Dyson, Chem.-Eur. J., 2014, 20, 4273; (b) J. Pape, K. L. Vikse, E. Janusson, N. Taylor and J. S. McIndoe, Int. J. Mass Spectrom., 2014, 373, 66.

23 V. Gabelica, N. Galic and E. De Pauw, J. Am. Soc. Mass Spectrom., 2002, 13, 946.

24 R. Bini, O. Bortolini, C. Chiappe, D. Pieraccini and C. Siciliano, J. Phys. B: At., Mol. Opt. Phys., 2007, 111, 598.

25 Spartan'14, version 1.1.0 (Sept 27 2013), Wavefunction Inc., Irvine CA, 2014.

26 M. J. Frisch, G. W. Trucks, H. B. Schlegel, G. E. Scuseria, M. A. Robb, J. R. Cheeseman, G. Scalmani, V. Barone, B. Mennucci, G. A. Petersson, H. Nakatsuji, M. Caricato, X. Li, H. P. Hratchian, A. F. Izmaylov, J. Bloino, G. Zheng, J. L. Sonnenberg, M. Hada, M. Ehara, K. Toyota, R. Fukuda, J. Hasegawa, M. Ishida, T. Nakajima, Y. Honda, O. Kitao, H. Nakai, T. Vreven, J. A. Montgomery Jr, J. E. Peralta, F. Ogliaro, M. Bearpark, J. J. Heyd, E. Brothers, K. N. Kudin, V. N. Staroverov, R. Kobayashi, J. Normand, K. Raghavachari, A. Rendell, J. C. Burant, S. S. Iyengar, J. Tomasi, M. Cossi, N. Rega, J. M. Millam, M. Klene, J. E. Knox, J. B. Cross, V. Bakken, C. Adamo, J. Jaramillo, R. Gomperts, R. E. Stratmann, O. Yazyev, A. J. Austin, R. Cammi, C. Pomelli, J. W. Ochterski, 
R. L. Martin, K. Morokuma, V. G. Zakrzewski, G. A. Voth, P. Salvador, J. J. Dannenberg, S. Dapprich, A. D. Daniels, Ö. Farkas, J. B. Foresman, J. V. Ortiz, J. Cioslowski and D. J. Fox, GAUSSIAN 09 (Revision D.1), Gaussian, Inc., Wallingford CT, 2009.

27 (a) B. D. Smith and T. N. Lambert, Chem. Commun., 2003, 2261; (b) J. T. Davis, P. A. Gale, O. A. Okunola, P. Prados,
J. C. Iglesias-Sanchez, T. Torroba and R. Quesada, Nat. Chem., 2009, 1, 138.

28 (a) A. V. Hill, Biochemistry, 1913, 7, 471; (b) S. Bhosale and S. Matile, Chirality, 2006, 18, 849.

29 E. Hernando, V. Soto-Cerrato, S. Cortés-Arroyo, R. PérezTomás and R. Quesada, Org. Biomol. Chem., 2014, 12, 1771.

30 E. E. Ambroggio, F. Separovic, J. H. Bowie, G. D. Fidelio and L. A. Bagatolli, Biophys. J., 2005, 89, 1874. 